\title{
Activity of Euphorbia splendens var. hislopii N.E.B. (Euphorbiaceae) Latex against Lymnaea columella (Say, 1817) (Pulmonata: Lymnaeidae), Intermediate Host of Fasciola hepatica, Linnaeus, 1758 (Trematoda: Fasciolidae). 2: Limited Field-testing
}

\author{
Mauricio Carvalho de Vasconcellos/ ${ }^{+}$, Alziro de Amorim*
}

Núcleo de Biologia e Controle de Endo e Ectoparasitas de Interesse Médico e Veterinário, Departamento de Biologia, Instituto Oswaldo Cruz-Fiocruz, Av. Brasil 4365, 21045-900 Rio de Janeiro, RJ, Brasil *Instituto de Veterinária, Universidade Federal

Rural do Rio de Janeiro, Seropédica, RJ, Brasil

The molluscicidal evaluation of Euphorbia splendens var. hislopii (Crown of thorns) against Lymnaea columella snails, intermediate host of Fasciola hepatica, in irrigation ditches of the Pisciculture Station at Universidade Federal Rural do Rio de Janeiro, was studied under limited field conditions. An aqueous solution of the latex at 5 $\mathrm{mg} / \mathrm{l}$ was tested in two irrigation ditches (experimental and control ditches), after initial sampling of the snail population present. Twenty-four hours after application of the product, it was verified that $97.4 \%$ of free L. columella snails and 100\% of snails of the same species captive in cages and used as sentinels at three points equidistant from the application site in the experimental ditch, died. For Biomphalaria tenagophila and Melanoides tuberculata snails, present in the experimental ditch, the mortality was $100 \%$, for the species Pomacea spp. the mortality was $40 \%$. No mortality was verified in the free mollusks, or in the sentinels in the ditch used as control. E. splendens var. hislopii latex is thus an efficient natural molluscicide, which may be used as an alternative control agent against $\mathrm{L}$. columella.

Key words: latex - Euphorbia splendens var. hislopii - Lymnaea columella-control - Fasciola hepatica

Fasciola hepatica Linnaeus, 1758, is a trematode causing fascioliasis, a disease that affects zootechnical breeding (Gordon 1955), resulting in serious damage to many countries' cattle-raising economy.

As regards Public Health, fascioliasis is worthy of somewhat closer attention, since man, as an occasional host, while being little susceptible to it, can catch the disease when eating aquatic or plants carrying or containing metacercariae (Oliveira 1932, Giovannoni \& Kubiak 1947, Freire \& Di Primio 1948).

In herds, this disease may bring about economic losses both by retarding growth in infected young animals (Oakley et al. 1979), and resulting in low fertility and abortions, as well as progressive loss in the production of meat and milk, and of the liver (Bundy et al. 1984, Ferrer et al. 1985, Urquhart et al. 1990, Hurtado et al. 1992) as well as leading to the death of infected animals (Reid et al. 1972).

In Brazil, fascioliasis was first described by Lutz (1921) and the first human case was reported by Rey (1958), in Mato Grosso do Sul, followed by references made by Santos and Vieira (1965), Correa and Fleury (1971), Amato Neto and Silva (1977), Baranski et al. (1977), Amaral and Bussetti (1979, 1980), Bussetti (1982).

Corresponding author. Fax +55-21-2560.6474. E-mail: mau@ioc.fiocruz.br

Received 19 March 2003

Accepted 6 August 2003
The states of Rio Grande do Sul (Ueno et al. 1982), Paraná and São Paulo (França 1967), Rio de Janeiro and Minas Gerais (De Rezende 1979), and Santa Catarina (Serra Freire \& Nuernberg 1992) are the most important endemic areas in our country.

Lymnaea columella (Say, 1817) is the most important intermediate host of $F$. hepatica, because of its wide distribution and because its occurrence is almost always associated with the disease (Rezende et al. 1973, Gonzales et al. 1974, Paraense 1982, 1983, Gomes et al. 1985, Amato et al. 1986).

The main preventive measures are based on control of the transmission of the disease by earth embankments around waterbeds containing host snails or by killing the snails. Some synthetic molluscicides in current used have the disadvantage of being general biocides, which destroy other species in the water. Plant molluscicides have therefore been widely investigated as possible substitutes, among these the latex of Euphorbia splendens var. hislopii.

The objective of the present study was to investigate the properties of the latex of E. splendens var. hislopii (Crown of thorns) plant, as a molluscicidal against $L$. columella snails, characterizing its activity range against snails under a limited field situation.

\section{MATERIALS AND METHODS}

Plant used - The species tested was Euphorbia splendens var. hislopii N.E.B. (syn. Euphorbia milii Des Moul. var. splendens (Hook.) Ursch \& Leandri) (Carter, 1994). The hislopii variety was the one used in the present research because it grows larger and can produce more latex. 
Latex collection - Samples from the latex of $E$. splendens var. hislopii were collected from plants cultivated in beds located near the Biology Department, Instituto Oswaldo Cruz-Fiocruz, Rio de Janeiro, RJ.

The raw latex that exuded on transversal sectioning, around $10 \mathrm{~cm}$ below the apical meristem of each branch was collected in a glass test tube closed with a screwcap and transported to the laboratory.

Evaluation of the molluscicidal effect in the field This bioassay was performed in an irrigation ditch at the Pisciculture Station of the Universidade Federal Rural do Rio de Janeiro, Seropédica, RJ.

The cemented ditch used was divided into two sections each measuring $80 \mathrm{~m}$ long by $0.36 \mathrm{~m}$ wide with $0.17 \mathrm{~m}$ depth of water. The water inflow was located between the sections, in a cemented box from which it entered the control section in a small and continuous flow with low turbulence and outflow leading into large natural tanks used for fish breeding. Both sections had marginal substrate and vegetation.

The molluscicidal latex was applied in one of the sections (the experimental ditch); the other served as control (control ditch).

The volume of water in the experimental ditch was estimated at 49001 and this was maintained by closing the entries and exits of the ditch. In the control ditch, the flow was kept continuous as an outlet for the flow, which was around $0.68 \mathrm{l} / \mathrm{s}$.

Both ditches presented samples of the target snails $L$. columella and the non-target species of mollusk Melanoides tuberculata (Müller, 1774), Biomphalaria tenagophila (Orbigny, 1835), and Pomacea sp., identified by the Department of Malacology, IOC, as well as the teleostean fish Lebistes reticulatus and aquatic insect larvae.

Samples of the water in the experimental and control ditches were collected before and after latex application so as to enable a comparative analysis of physicochemical parameters.

The concentration of the latex solution used in the test was $5 \mathrm{mg} / \mathrm{l}$ ( 3 times larger than that determined in the laboratory (Vasconcellos 1996), prepared from a stocksolution of $1000 \mathrm{mg} / \mathrm{l}$ of the latex (collected on the same day of the experiment and from the same original location as used by Vasconcellos 1996). This concentration was calculated from the total volume of water to be treated in the experimental ditch, using $24.5 \mathrm{ml}$ of in natura latex, with water from the experimental ditch.

The latex solution was applied with a watering can, over the entire experimental ditch, so that it would be essentially homogenous. This solution stayed in the experimental ditch during $24 \mathrm{~h}$ after application, after this period, the regular circulation of water in and out of the ditch was restored.

Snails sampling - Sampling of the snails was made from both ditches before application and $24 \mathrm{~h}$ after application of the latex solution in the experimental ditch.

Samplings were performed by three individuals, at three specific points $(0 \mathrm{~m} ; 40 \mathrm{~m} ; 80 \mathrm{~m})$, in $1 \mathrm{~m}^{2}$, for a period of $20 \mathrm{~min}$, in both ditches (man/time sampling) (Olivier \& Schneiderman 1956).
The snails gathered before application in the substrate and on the water surface were collected by forceps, separated by species, quantified, and returned to their habitat, at the same spot where they had been collected.

In the sampling effected $24 \mathrm{~h}$ after latex application, all of the collected animals (live and dead) were packaged and taken to the laboratory to be quantified by species. The ones that were alive were placed in tanks for $48 \mathrm{~h}$ to recover.

Sentinel snails - Before application of the latex solution, six perforated plastic containers measuring $5 \times 3$ $\mathrm{cm}$ (protection flasks of photographic rolls), were immersed in the ditches, as cages, each containing 10 samples of $L$. columella, three in each ditch at the three sampling locations.

Physicochemical analysis of the latex solutions Following the method employed by the State Environmental Laboratory Feema (1979), some physicochemical parameters were analyzed, such as: conductivity $(\mu \mathrm{mho} / \mathrm{cm})$, alkalinity $\left(\mu \mathrm{g} / \mathrm{l} \mathrm{CaCO}_{3}\right)$, chlorides $(\mathrm{mg} / \mathrm{l} \mathrm{Cl}-)$, calcium hardness $(\mathrm{mg} / \mathrm{l})$ and $\mathrm{pH}$ of the latex stock-solution $(1000 \mathrm{mg} / \mathrm{l})$, used in the field test and prepared using the water from the snail's habitat.

\section{RESULTS}

Evaluation of the molluscicidal effect of the latex in the field - Table I shows the molluscicidal activity of $E$. splendens var. hislopii latex, at a concentration of $5 \mathrm{mg} / \mathrm{l}$, against $L$. columella, in a lentic habitat.

The results showed $97.4 \%$ mortality of $L$. columella, $24 \mathrm{~h}$ after application of the aqueous latex solution in the experimental ditch. In the control ditch, without treatment, there was no snail mortality.

Table II shows the mortality results in samplings of $L$. columella, snails immersed in underwater cages in the treated ditch. Mortality was $100 \%$ after $24 \mathrm{~h}$ contact, at all three locations. There was no mortality of caged snails in the control ditch (untreated) (Table III).

Table IV shows the results of the latex solution action at $5 \mathrm{mg} / \mathrm{l}$ against other mollusk species (B. tenagophila, M. tuberculata, and Pomacea sp.), present in the ditches. It is seen that mortality was $100 \%$ for the species $B$. tenagophila and M. tuberculata; and $40 \%$ for Pomacea $\mathrm{sp}$. In the untreated ditch, no mortality was observed in these species. No mortality was observed either among fish (Lebistes reticulatus) or in larvae of aquatic insects present in the ditches (experimental and control ditches).

\section{TABLE I}

Molluscicidal action of the latex of Euphorbia splendens var. hislopii at a concentration of $5 \mathrm{mg} / \mathrm{l}$, against Lymnaea columella in a natural habitat (irrigation ditch)

\begin{tabular}{lcccccc}
\hline & \multicolumn{4}{c}{ Number of L. columella } \\
\cline { 2 - 3 } & \multicolumn{2}{c}{$\begin{array}{c}\text { Before } \\
\text { application }\end{array}$} & & \multicolumn{2}{c}{$\begin{array}{c}\text { After } \\
\text { application }\end{array}$} & Mortality \\
\cline { 2 - 3 } Groups & Alive & Dead & & Alive & Dead & $(\%)$ \\
\hline Control & 223 & 0 & & 129 & 0 & 0 \\
Experimental & 179 & 0 & & 4 & 153 & 97.4 \\
\hline
\end{tabular}




\section{TABLE II}

Exposure of Lymnaea columella (sentinel snails) at three points of an experimental ditch to the latex of Euphorbia splendens var. hislopii, at a concentration of $5 \mathrm{mg} / \mathrm{l}$, for $24 \mathrm{~h}$. The cages were placed under the water

\begin{tabular}{|c|c|c|c|c|c|}
\hline \multirow{3}{*}{$\begin{array}{l}\text { Distance } \\
\text { between } \\
\text { cages }(\mathrm{m})\end{array}$} & \multicolumn{5}{|c|}{ Number of L. columella } \\
\hline & \multicolumn{2}{|c|}{$\begin{array}{c}\text { Before } \\
\text { application }\end{array}$} & \multicolumn{2}{|c|}{$\begin{array}{l}24 \mathrm{~h} \text { after } \\
\text { application }\end{array}$} & \multirow{2}{*}{$\begin{array}{c}\text { Mortality } \\
(\%)\end{array}$} \\
\hline & Alive & Dead & Alive & Dead & \\
\hline 0 & 10 & 0 & 0 & 10 & 100 \\
\hline 40 & 10 & 0 & 0 & 10 & 100 \\
\hline 80 & 10 & 0 & 0 & 10 & 100 \\
\hline
\end{tabular}

TABLE III

Exposure of Lymnaea columella (sentinel snails) at three points of the untreated control ditch for $24 \mathrm{~h}$. The cages were placed under the water

\begin{tabular}{lcccccc}
\hline & \multicolumn{3}{c}{ Number of L. columella } \\
\cline { 2 - 3 } $\begin{array}{l}\text { Distance } \\
\text { between }\end{array}$ & \multicolumn{2}{c}{$\begin{array}{c}\text { Before } \\
\text { application }\end{array}$} & & \multicolumn{2}{c}{$\begin{array}{c}\text { 24h after } \\
\text { application }\end{array}$} & Mortality \\
\cline { 2 - 3 } cages (m) & Alive & Dead & & Alive & Dead & $(\%)$ \\
\hline 0 & 10 & 0 & & 10 & 0 & 0 \\
40 & 10 & 0 & & 10 & 0 & 0 \\
80 & 10 & 0 & & 10 & 0 & 0 \\
\hline
\end{tabular}

Physicochemical analysis of the latex solutions - Table $\mathrm{V}$ shows the results of the physical-chemical analysis. It is observed that the data for the parameters analyzed were always kept below the maximum values obtained in the water of habitat of L. columella where collections were carried out.

\section{DISCUSSION}

This study was carried out with snails in the field, in irrigation ditches at the Pisciculture Station of the Universidade Federal Rural Campus in Rio de Janeiro. The season of the year when the test was performed was considered to be atypical due to the long period of drought from winter to spring, which considerably altered the habitat, resulting in a reduced mollusk population.

The fact that E. splendens var. hislopii latex showed high activity in a field situation makes it a promising natural
TABLE V

Values found in some physicalchemical parameters of the mother-solution used in the field test (E), with the latex of Euphorbia splendens var. hislopii, against Lymnaea columella, at a concentration of $1000 \mathrm{mg} / \mathrm{l}$

\begin{tabular}{lcc}
\hline & \multicolumn{2}{c}{ Maximum values } \\
\cline { 2 - 3 } & $\mathrm{E}$ & Habitat \\
\hline Conductivity $(\mu \mathrm{mho} / \mathrm{cm})$ & 150 & 350 \\
Alkalinity $\left(\mathrm{mg} / \mathrm{CaCO}_{3}\right)$ & 16 & 28 \\
Chloride $\left(\mathrm{mg} / \mathrm{l} \mathrm{Cl}^{-}\right)$ & 10.7 & 18.1 \\
Calcium $(\mathrm{mg} / \mathrm{l})$ & 10.4 & 11.2 \\
$\mathrm{pH}$ & 6.5 & 6.7 \\
\hline
\end{tabular}

molluscicide. The result is in accord with Mendes et al. $(1992,1997)$ and Baptista et al. (1992), who have tested the latex in lentic and lotic environments, respectively, in concentrations between 5 and $12 \mathrm{mg} / \mathrm{l}$ against intermediate hosts of Schistosoma mansoni, where they also found $100 \%$ mortality.

The mortality rate for the free animals $(97.4 \%)$ suggests that the surviving mollusks (2.6\%) may have escaped the product's action because they could have been out of the water or else protected in some way at the time of its application. However, the utilization of sentinel snails in underwater cages, in three locations in the treated ditch, confirmed the efficiency of the product with $100 \%$ mortality.

With reference to the difference in the number of animals collected in samplings before and after the ditch treatment, it is assumed that these animals might have moved, while trying to escape the product's action.

As to the remaining species of mollusk present in the habitat of L. columella, the mortality rate of $100 \%$ for $B$. tenagophila and M. tuberculata can be considered satisfactory, since these are intermediate hosts of $S$. mansoni and Paragonimus westermanii (Kelbert 1978), respectively. Now, for Pomacea sp., the mortality rate was lower (40\%), also observed by Mendes et al. (1992) and Baptista et al. (1992), which indicates that this species is more resistant to the molluscicide than M. tuberculata, since both of them contain an operculum that can remain closed for as long as adverse conditions to the means persist.

TABLE IV

Mortality of Biomphalaria tenagophila, Melanoides tuberculata and Pomacea sp. present in a habitat of Lymnaea columella before and after application of the latex of Euphorbia splendens var. hislopii, at a concentration of $5 \mathrm{mg} / 1$

\begin{tabular}{|c|c|c|c|c|c|c|c|c|c|c|}
\hline & \multicolumn{10}{|c|}{ Number of snails } \\
\hline & \multicolumn{5}{|c|}{ Control group } & \multicolumn{5}{|c|}{ Experimental group } \\
\hline & \multicolumn{2}{|c|}{ Before } & \multicolumn{2}{|c|}{ After } & \multirow{2}{*}{$\begin{array}{c}\text { Mortality } \\
(\%)\end{array}$} & \multicolumn{2}{|c|}{ Before } & \multicolumn{2}{|c|}{ After } & \multirow{2}{*}{$\begin{array}{r}\text { Mortality } \\
(\%)\end{array}$} \\
\hline & Alive & Dead & Alive & Dead & & Alive & Dead & Alive & Dead & \\
\hline B. tenagophila & 1 & - & 20 & - & 0 & 37 & - & - & 76 & 100 \\
\hline M. tuberculata & 215 & 4 & 250 & - & 0 & 251 & 21 & - & 425 & 100 \\
\hline Pomacea sp. & 4 & - & 6 & - & 0 & - & - & 12 & 3 & 40 \\
\hline
\end{tabular}


With regard to the toxicology of E. splendens var. hislopi latex Marston \& Hecker $(1983,1984)$ identified several diterpene esters, considered to be irritants, but did not confirm carcinogenic properties. Pharmacologically active substances, such as citrostadiene (Ia), present in extracts of this plant, have already been stated by Rao and Sussela (1982), as having anti-inflammatory action, in addition to the presence of a macrolide, lasiodiplodin, which has shown antileukemic activity in mice, according to Lee et al. (1982). When performing a test of skin and ocular irritability in rabbits, Freitas et al. (1991) observed that the latex was not irritating in concentrations below $3500 \mathrm{mg} / 1(0.35 \%)$, nonetheless the use of gloves and protective glasses when handling the raw product was recommended.

Schall et al. (1991) observed that the latex does not present mutagenic activity in Salmonella typhimurium (Ames Test) or acute toxicity in the presence of Photobacterium phosphoreum (Microtox); the acute oral toxicity in mice was low and the lethal dosage $\left(\mathrm{LC}_{50}\right)$ was above $5 \mathrm{~g} / \mathrm{kg}$ (Mattos et al. 1989). Now the sub-acute toxicity test (14 days) resulted in diarrhoea and weight loss in rats, although no deaths occurred in dosages lower than $0.25 \mathrm{~g} / \mathrm{kg}$ (Lopes et al. 1992). However, Souza et al. (1994) showed that at dosages above that level, the latex proved to be embryotoxic, although no fetal or genotoxic malformation (teratogenicity), was observed by Zamith et al. (1994).

In eco-toxicological studies, using fish, algae and bacteria, no toxic activity was observed with these species, which were considered as non-target, in low concentrations (Oliveira-Filho \& Paumgartten 1994).

Regarding the cost-benefit in the use of E. splendens var. hislopii as a molluscicide, perspectives are quite satisfactory, according to Baptista et al. (1994), because, after one year and a half of the planting, the average productivity of the latex was 11 per $8 \mathrm{~m}^{2}$, which would be enough to treat as much as 97,200 liters of water, in a concentration of $12 \mathrm{mg} / \mathrm{l}$, and which could be done by the rural communities themselves.

These results indicate that E. splendens var. hislopii latex is an effective molluscicide that can be used as an alternative method to control L. columella.

\section{REFERENCES}

Amaral ADF, Busetti ET 1979. Fasciolose hepática humana no Brasil. Rev Inst Med Trop São Paulo 21: 141-145.

Amaral ADF, Busetti ET 1980. Observações preliminares sobre a fasciolose hepática humana em Curitiba. In Cong Soc Bras Parasitol 4, Campinas, São Paulo, p. 59.

Amato Neto V, Silva LJ 1977. Infecção humana por Fasciola hepatica no Brasil: relato de um novo caso e análise da questão. Rev Inst Med Trop São Paulo 19: 275-277.

Amato SB, Rezende HEB, Gomes DC, Serra Freire NM 1986. Epidemiology of Fasciola hepatica infection in the Paraíba River Valley, São Paulo, Brasil. Vet Parasitol 22: 275-284.

Baptista DF, Vasconcellos MC, Lopes FEF, Silva IP, Schall VT 1992. Evaluation of the molluscicidal property of Euphorbia splendens var. hislopii (N.E.B.) (Euphorbiaceae) - 2. Investigation in lotic habitat. Mem Inst Oswaldo Cruz 87: 549-553.

Baptista DF, Vasconcellos MC, Lopes FEF, Silva IP, Schall VT 1994. Perspectives of using Euphorbia splendens as a molluscicide in schistosomiasis control programs. Southeast Asian J Trop Publ Health 25: 419-424.

Baransky MC, Amaral ADF, Carneiro Filho M, Silva RF, Silveira HB, Cunha LAM, Magni NR 1977. Novos casos autóctones de fasciolose hepática humana em Curitiba (Estado do Paraná-Brasil). An Fac Med Paraná 20: 7-25.

Bundy DAP, Arambulo Iii PV, Grey CL 1984. La fascioliasis en Jamaica: Aspectos epidemiologicos y economicos de una zoonosis parasitaria transmitida por caracoles. Bol Sanit Panam 96: 1-19.

Busetti ET 1982. Informações adicionais sobre a fasciolose hepática em Curitiba (Estado do Paraná-Brasil). Rev Inst Med Trop São Paulo 24: 104-106.

Carter S 1994. A preliminary classification of Euphorbia subgenus Euphorbia. Ann Missouri Bot Gard 81: 368-379.

Correa MOA, Fleury GC 1971. Fasciolose hepática humana: novo caso autóctone. Rev Soc Bras Med Trop 5: 267-270.

De Rezende HEB 1979. Retrospectiva da fasciolose bovina no Brasil. In AAH Beck, HJH de Melo, I Bianchin, MRJ Soares, Anais do Seminário Nacional sobre Parasitoses dos Bovinos, Campo Grande, Embrapa/CNPGC, p.133-143.

Feema-Fundação Estadual de Engenharia e Meio Ambiente, 1979. Métodos de Análises Físico-químicas da Água, Vol. III, Série Didática, 14/79, DICOMT, Rio de Janeiro

Ferrer JR, Perera G, Yong M 1985. Estudio de los moluscos fluviátiles de una localidad afectada por un brote de fascioliasis. Rev Cub Med Trop 37: 155-160.

França I 1967. Fasciolose hepática em bovinos no Vale do Paraíba, Estado de São Paulo - Brasil. Arch Esc Vet Minas Gerais 19: 157-159.

Freire JJ, Di Primio RA 1948. Fauna zooparasitária riograndense. Veterinária 2: 36-44.

Freitas JCB, Presgrave OAF, Fingola FF, Menezes MAC, Vasconcellos MC, Schall VT, Paumgartten FJR 1991. Toxicological study of the molluscicidal latex of Euphorbia splendens: irritant action on skin and eye. Mem Inst Oswaldo Cruz 86(Suppl. II): 87-88.

Giovannoni M, Kubiak GVL 1947. Fauna parasitológica paranaense. IV - Lista prévia da ocorrência de helmintos em animais domésticos. Arq Biol Tecnol 2: 225-232.

Gomes DC, Serra Freire NM, Amato SB, Rezende HEB 1985. Análise do envolvimento de Lymnaea columella e Stenophysa marmorata na epidemiologia da fasciolose hepática no Vale do Paraíba. IX Cong Soc Bras Parasitol, Resumos, p. 99.

Gonzales JC, Tomé JW, Gonçalves PC, Oliveira CBM 1974. Lymnaea columella hospedeiro intermediário de Fasciola hepatica (Lin. 1758) no Rio Grande do Sul, Brasil. Arq Fac Med Vet Rio Grande do Sul 2: 37-40.

Gordon HM 1955. Some aspects of fascioliasis. Aust Vet J 31 : 182-188.

Hurtado AAC, Sánchez IE, Romero HQ 1992. Frecuencia de fasciolasis hepática en bovinos sacrificados en las plantas Tipo Inspección Federal en México de los años 1979-1987. Vet Méx 23: 339-342.

Lee KH, Hayashi N, Okano M, Hall IH, Wu RY, Mcphail A 1982. Lasiodiplodin, a potent antileukemic macrolide from Euphorbia splendens. Phytochemistry 21: 1119-1121.

Lopes MC, Presgrave RF, Alves EN, Rocha RN, Soares RMD, Coelho SCB, Vasconcellos MC, Schall VT, Paumgartten FJR 1992. Estudo toxicológico do látex moluscicida da "Coroa-de-Cristo" (Euphorbia splendens var. hislopii). II. Exposição sub-aguda por via oral. Anais da VII Reunião Anual da Federação de Sociedades de Biologia Experimental, Caxambu, MG, Resumos, p. 229.

Lutz A 1921. Sobre a ocorrência de Fasciola hepatica no Estado do Rio de Janeiro. Bol Inst Oswaldo Cruz 1: 9-13.

Marston A, Hecker E 1983. On the active principles of the 
Euphorbiaceae VI. Planta Medica 47: 141-147.

Marston A, Hecker E 1984. Active principles of the Euphorbiaceae VII. Planta Medica 4: 285-364.

Mattos RC, Vasconcellos MC, Lopes MC, Souza CAM, Alves EN, Farias M, Schall VT, Paumgartten FJR 1989. Estudo toxicológico do látex moluscicida da coroa-de-cristo (Euphorbia splendens var. hislopii). I - Ensaios preliminares. Anais da IV Reunião Anual da Federação de Sociedades de Biologia Experimental, Caxambu, MG, Resumo, p. 320.

Mendes NM, Baptista DF, Vasconcellos MC, Schall VT 1992. Evaluation of the molluscicidal properties of Euphorbia splendens var. hislopii (N.E.B.) (Euphorbiaceae) - 1. Experimental test in a lentic habitat. Mem Inst Oswaldo Cruz 87: 21-23.

Mendes NM, Vasconcellos MC, Baptista DF, Rocha RS, Schall VT 1997. Evaluation of the molluscicidal properties of Euphorbia splendens var. hislopii (N.E.B.) latex: experimental test in an endemic area in the state of Minas Gerais, Brazil. Mem Inst Oswaldo Cruz 92: 719-724.

Oakley GA, Owen B, Knapp NH 1979. Production effects of subclinical liver fluke infection in growing dairy heifers. Vet Rec 104: 503-507.

Oliveira A 1932. Distribuição geográfica de algumas zoonoses existentes no Rio Grande do Sul. Rev Zootec 18: 1-10.

Oliveira Filho EC, Paumgartten FJR 1994. Estudo ecotoxicológico do látex moluscicida da "coroa de cristo" (Euphorbia milii var. hislopii). Anais da IX Reunião Anual da Federação de Sociedades de Biologia Experimental, Caxambu, MG, Resumos, 12.6.

Olivier L, Schneiderman M 1956. A method for estimating the density of aquatic snail populations. Exper Parasitol 5: 109-117.

Paraense WL 1982. Lymnaea viatrix and Lymnaea columella in the neotropical region: a distributional outline. Mem Inst Oswaldo Cruz 77: 181-188.

Paraense WL 1983. Lymnaea columella in Northern Brazil. Mem Inst Oswaldo Cruz 78: 477-482.

Rao CB, Sussela K 1982. Chemical examination of Euphorbia splendens Boj. Indian J Chem 21B: 495-496.

Reid J, Doyle F, Armour JJ, Jennings J 1972. Fasciola hepatica infection in cattle. Vet Rec 90: 486.

Rey L 1957. Fasciola hepatica no gado do Rio Grande do Sul; investigação sobre a possibilidade de ocorrência de casos humanos. Rev Bras Malariol 9: 473-483.
Rey L 1958. Primeiro encontro de ovos de Fasciola hepatica em inquérito helmintológico de populações brasileiras (Campo Grande, Mato Grosso). Rev Paul Med 53: 60.

Rezende HEB, Araújo JLB, Gomes PAC, Nuernberg S, Pimentel Neto M, Oliveira GP, Mello RP 1973. Notas sobre duas espécies de Lymnaea Lamark, 1799, hospedeiros intermediários de Fasciola hepatica L, no Estado do Rio de Janeiro (Mollusca, Gastropoda, Basommatophora, Lymnaeidae). Arq Univ Fed Rur do Rio de Janeiro 3: 21-23.

Santos L, Vieira TE 1965. Considerações sobre os sete primeiros casos de fasciolose humana no Vale do Paraíba, Estado de São Paulo. Rev Inst Adolfo Lutz 25: 95-100.

Schall VT, Vasconcellos MC, Valent GU, Sato MIZ, Furlan EV, Sanchez PS 1991. Evaluation of the genotoxic activity and acute toxicity of Euphorbia splendens latex, a molluscicide for the control of schistosomiasis. Brazilian J Med Biol Res 24: 573-582.

Serra Freira NM, Nuernberg S 1992. Dispersão geopolítica da ocorrência da Fasciola hepatica no estado de Santa Catarina, Brasil. Mem Inst Oswaldo Cruz 87: 263-269.

Souza CAM, Carvalho RR, Vollmer RS, Kuriyama SN, Rodrigues RPS, Alves EM, Paumgartten FJR 1994. Estudo da embriofetotoxicidade do látex moluscicida da coroa de cristo (Euphorbia splendens var. hislopii) em ratos. Anais da IX Reunião Anual da Federação de Sociedades de Biologia Experimental, Caxambu, MG, Resumos, p. 288.

Ueno H, Gutierres VC, Mattos MJT, Muller G 1982. Fascioliasis problem in ruminants in Rio Grande do Sul, Brazil. Vet Parasitol 11: 185-191.

Urquhart GM, Armour J, Duncan JL, Dunn AM, Jennings FN 1980. Parasitologia Veterinária, Guanabara Koogan, Rio de Janeiro, $306 \mathrm{pp}$.

Vasconcellos MC 1996. Ação do Látex de Euphorbia splendens var. hislopii N.E.B. (Euphorbiaceae) sobre Lymnaea columella (Say, 1817) (Pulmonata: Lymnaeidae), Hospedeiro Intermediário de Fasciola hepatica Linnaeus, 1758 (Trematoda: Fasciolidae), em Laboratório e Campo, MSc Thesis, UFRRJ, 75 pp.

Zamith HPS, Otto SS, Paumgartten FJR 1994. Avaliação da genotoxicidade do látex moluscicida da coroa de cristo (Euphorbia splendens var. hislopii): teste de troca de cromátides irmãs em células V79. Anais da IX Reunião Anual da Federação de Sociedades de Biologia Experimental, Caxambu, MG, Resumos, p. 289. 